\title{
Avaliação da imunidade passiva em bezerros nascidos de vacas imunizadas com vacina contra rotavírus
}

[Evaluation of passive immunity in calves born from cows immunized with anti-rotavirus vaccine]

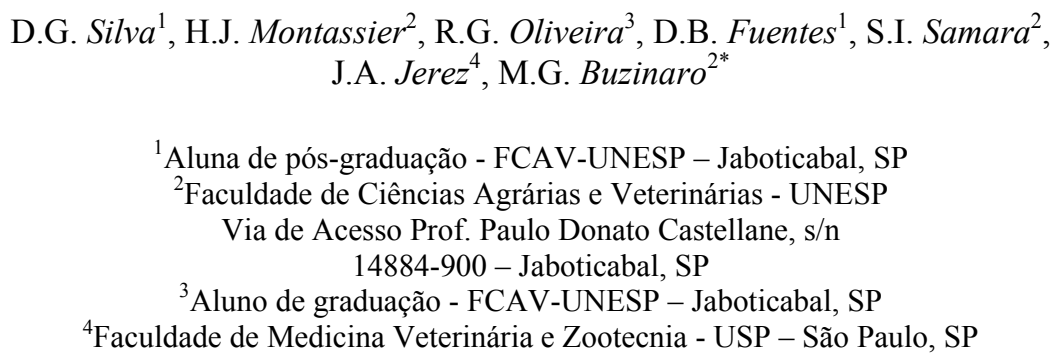

\section{RESUMO}

Com o objetivo de monitorar a imunidade passiva em bezerros alimentados com colostro de vacas imunizadas e não imunizadas com vacina contra rotavírus, foram determinados títulos de anticorpos em amostras de sangue e colostro de 26 vacas da raça Holandesa no dia do parto e de seus bezerros, à zero, às 24, 48 horas e aos sete, 14, 21, 28 dias de idade, pelo ensaio imunoenzimático. Tanto no soro sangüíneo como no colostro, os títulos dos isótipos $\operatorname{IgG}$, IgG1 e IgG2 foram mais elevados no grupo dos animais vacinados, porém somente no colostro o aumento foi significativo. Os bezerros alimentados com o colostro das vacas vacinadas apresentaram títulos mais altos dos isótipos $\operatorname{IgG}, \operatorname{IgG} 1, \operatorname{IgG} 2, \operatorname{IgA}$ e $\operatorname{IgM}$, após a ingestão do colostro, sendo constatado aumento significativo apenas para os títulos do isótipo IgG2. Amostras positivas para rotavírus foram detectadas nos dois grupos experimentais a partir dos sete dias de idade. A vacinação materna não protegeu efetivamente os bezerros das infecções naturais por rotavírus, pois, apesar de aumentar os títulos séricos de anticorpos anti-rotavírus nos animais vacinados, não foi capaz de impedir a ocorrência da rotavirose nos bezerros alimentados com o colostro das vacas imunizadas.

Palavras-chave: bovino, colostro, imunidade passiva, rotavírus, vacina

\begin{abstract}
Passive immune response in calves fed colostrum from immunized and nonimmunized cows by anti-rotavirus vaccine was monitored. Titers of antibodies were determined by immunoenzymatic assay in blood and colostrum sampled at parturition day from 26 Holstein cows as well as in blood from their calves collected at 0, 24, and 48 hours and seven, 14, 21, and 28 days after birth. In serum and colostrum, IgG, IgG1, and IgG2 antibody titers were higher in vaccinated animals; however, this increase was only significant in colostrum. The calves fed colostrum from vaccinated cows showed higher $\operatorname{IgG}$, IgG1, IgG2, IgA, and IgM isotypes titers after the ingestion of colostrum, being evidenced significant increase only for IgG2 titers. Positive samples for rotavirus were detected in both experimental groups since seven days after birth. Results showed that maternal vaccine failed to protect effectively the calves from natural infections by rotavirus, though it increased the antirotavirus antibody titers in vaccinated animals, but was not capable to impair the occurrence of rotaviruses in the calves fed colostrum from immunized cows.
\end{abstract}

Keywords: cattle, colostrum, passive immunity, rotavirus, vaccine

Recebido em 29 de outubro de 2007

Aceito em

*Autor para correspondência (corresponding author)

E-mail: glorinha@fcav.unesp.br 


\section{INTRODUÇÃO}

Rotavírus são apontados como um dos principais agentes etiológicos de diarréia em bezerros com idade inferior a três semanas, resultando em grandes perdas econômicas à pecuária de leite e corte (Tzipori, 1981; Snodgrass et al., 1986; Lucchelli et al., 1992).

O fato de os bezerros nascerem praticamente desprovidos de anticorpos associado ao desenvolvimento incompleto do sistema imune torna extremamente importante a ingestão do colostro para a aquisição de anticorpos maternos e proteção contra a diarréia por rotavírus (Saif et al., 1984; Robison et al., 1988; Tizard, 2002).

Vários estudos têm demonstrado que a vacinação parenteral de vacas prenhes com vacinas de rotavírus vivo ou inativado é capaz de elevar significativamente os títulos de anticorpos antirotavírus séricos, os quais são transferidos para o colostro e o leite e protegem passivamente os bezerros de infecções experimentais (Castrucci et al., 1988; Tsunemitsu et al., 1989). Entretanto, em estudos a campo, a eficácia da vacinação materna é variável, sendo constatados diferentes resultados quanto ao nível de proteção dos bezerros à exposição viral (Bellinzoni et al., 1989; Kohara et al., 1997).

A imunoglobulina $\mathrm{G}$ (IgG) é considerada a mais importante na imunização passiva de bezerros (Menanteau-Horta et al., 1985), sendo altos títulos do isótipo IgG1 associados à proteção contra diarréia por rotavírus (Saif et al., 1983; Fernandez et al., 1998). Bezerros com altos níveis séricos de IgG1 apresentam significativamente período mais curto de diarréia durante curso clínico, quando comparados com bezerros com baixos níveis séricos de IgG1, após o desafio com rotavírus (Parreño et al., 2004). Verifica-se ainda aumento nos títulos dos isótipos $\operatorname{IgA}$ e $\operatorname{IgM}$ nos animais com baixos títulos séricos de $\operatorname{IgG1}$, após a inoculação viral (Fernandez et al., 1998; Parreño et al., 2004).

O objetivo deste trabalho foi monitorar, em condições de campo, a imunidade passiva em bezerros alimentados com colostro de vacas imunizadas e não imunizadas com vacina comercial de rotavírus e determinar sua relação com a detecção de rotavírus nas fezes.

\section{MATERIAL E MÉTODOS}

Para os estudos de imunidade passiva, foi

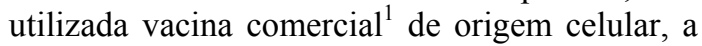
qual continha culturas inativadas de rotavírus bovino (estirpe NCDV-Lincoln-G6P[1]), coronavírus bovino, bacterina de Escherichia coli e toxóide de Clostridium perfringens tipo C.

Vinte e seis vacas da raça Holandesa, prenhes, com idade entre três e oito anos, oriundas de dois rebanhos de leite do estado de São Paulo, foram distribuídas aleatoriamente em dois grupos experimentais. Todas as vacas apresentavam anticorpos anti-rotavírus devido à ocorrência de infecção natural. Treze vacas (grupo I) receberam duas doses da vacina, administrada pela via intramuscular cerca de 60 e 30 dias antes da data prevista para o parto. As outras treze vacas (grupo II) não foram vacinadas, sendo utilizadas como grupo-controle. Imediatamente após o parto, todos os vinte e seis bezerros foram separados das vacas, transferidos para baias individuais e alimentados com quatro a seis litros de colostro das próprias mães, por meio de mamadeira, divididos em dois repastos. Os bezerros foram acompanhados diariamente durante 28 dias, anotando-se a ocorrência de enterites e/ou outras enfermidades.

As amostras de colostro das vacas dos grupos I e II foram colhidas em frascos plásticos estéreis, imediatamente após o parto, por meio de ordenha manual de aproximadamente $20 \mathrm{ml}$ de colostro de cada quarto do úbere. Para obtenção do soro lácteo, foi realizado o tratamento do colostro com renina ${ }^{2}$ (Sant'ana e Birgel, 2003). Posteriormente, as alíquotas de soro lácteo foram congeladas à temperatura de $-20^{\circ} \mathrm{C}$ até $\mathrm{O}$ momento dos exames laboratoriais.

As amostras de sangue das vacas foram colhidas mediante a punção da veia jugular, no dia do parto, utilizando-se o sistema de colheita a vácuo $^{3}$, em tubos de vidro siliconizado sem anticoagulante. As amostras de sangue dos bezerros foram colhidas em sete momentos: à zero hora (antes da ingestão do colostro), às $24 \mathrm{e}$ às 48 horas, aos sete, 14,21 , e 28 dias de idade.

\footnotetext{
${ }^{1}$ Laboratórios Pfizer Ltda. - Guarulhos, Brasil.

${ }^{2}$ Estrella, Fábrica de Coalhos e Coagulantes - Valinhos, Brasil.

${ }^{3}$ BD Vacutainer, Becton Dickinson Ind. Cirurg. Ltda. - Juiz de Fora, Brasil.
} 
As amostras de fezes foram colhidas nas mesmas datas especificadas anteriormente para colheita de sangue dos bezerros, as quais foram obtidas diretamente da ampola retal, em sacos plásticos e mantidas sob refrigeração até a chegada ao laboratório, onde foram congeladas à temperatura de $-20^{\circ} \mathrm{C}$ até o momento da análise. As amostras de fezes também foram classificadas visualmente em normais ou diarréicas. As amostras de fezes de consistência líquida foram consideradas diarréicas, enquanto as amostras de consistência firme ou pastosa foram classificadas como não diarréicas.

A determinação dos títulos dos isótipos de anticorpos anti-rotavírus, no soro e no colostro das vacas e no soro dos bezerros, foi realizada pelo ensaio imunoenzimático (EIE) indireto, como preconizado por Fernandez et al. (1998), com algumas modificações.

O volume e a diluição ótima dos reagentes foram determinados por meio de titulação em bloco, usando amostras de soro, previamente conhecidas, como referência positiva e negativa. As lavagens das microplacas ${ }^{4}$ foram realizadas com PBS (pH 7,4) contendo $0,05 \%$ de Tween 20 (PBS-T), e as diluições foram feitas com PBS-T contendo $1,5 \%$ de ovoalbumina ${ }^{5}$. As incubações foram realizadas durante $1 \mathrm{~h}$ a $37^{\circ} \mathrm{C}$, em câmara úmida. Volumes de $50 \mu \mathrm{l} /$ cavidade foram utilizados para todos os reagentes. Resumidamente, as microplacas, de fundo plano, com 96 cavidades foram sensibilizadas com diluição ótima de rotavírus semi-purificado (1:8) em tampão carbonato bicarbonato $0,05 \mathrm{M}, \mathrm{pH} 9,6$ (TCB) overnight a $4^{\circ} \mathrm{C}$. Na fase seguinte, foi adicionada a solução bloqueadora, constituída de ovoalbumina a 1,5\% diluída em TCB. Em seguida, foram adicionadas em duplicata as diluições únicas e ideais das amostras de soro sangüíneo (1:25 a 1:800), colostro (1:25 a 1:6400) e das amostras de referência positiva e negativa (1:25 a 1:800). As microplacas receberam, na fase subseqüente, diluição ideal do conjugado imunoenzimático ${ }^{6}$ anti-IgG (1:1000), anti-IgG1 (1:2500), anti-IgG2 (1:500), anti-IgA (1:500) e anti-IgM (1:4000) bovina conjugados à peroxidase. Para completar a reação, foram adicionados às microplacas solução cromógena

\footnotetext{
${ }^{4}$ Maxisorp, Nunc - Roskilde, Dinamarca.

${ }^{5}$ Sigma Chemical Company - St. Louis, EUA.

${ }^{6}$ Bethyl Laboratories - Montgomery, EUA.
}

de ortofenilenodiamina ${ }^{7}$ (OPD) diluída em tampão citrato de sódio fosfato $(\mathrm{pH} 4,9-5,2)$ acrescida de peróxido de hidrogênio $\left(\mathrm{H}_{2} \mathrm{O}_{2}\right)$ a $3 \%$. Foi realizada uma nova incubação durante 15 minutos à temperatura ambiente, ao abrigo da luz. O bloqueio da atividade enzimática foi realizado com a adição de solução de ácido clorídrico $(\mathrm{HCl}) 2 \mathrm{M}$.

As leituras das densidades ópticas (DO) da reação foram realizadas em leitor de microplacas $^{8}$, a um comprimento de onda de 490nm. A média das DO de cada amostra teste foi transformada em valor de título de anticorpos anti-rotavírus.

A análise da presença de rotavírus nas fezes foi realizada pela técnica de eletroforese em gel de poliacrilamida (EGPA), segundo as recomendações de Pereira et al. (1983) e pelo EIE para rotavírus e adenovírus ${ }^{9}$, para a confirmação da presença de rotavírus do grupo antigênico A, segundo Pereira et al. (1985).

$\mathrm{Na}$ técnica de EGPA, em $0,4 \mathrm{ml}$ de suspensão fecal, previamente tratada por freon $\mathrm{TF}$ (triclorofluoretano), foram adicionados $40 \mu \mathrm{lde}$ lauril sulfato de sódio (SDS) a 10\%, incubandose a mistura a $37^{\circ} \mathrm{C}$ por 30 minutos. A seguir, o RNA foi extraído utilizando-se uma mistura de fenol/clorofórmio. Após centrifugação, o sobrenadante foi transferido para tubos tipo Eppendorf contendo $40 \mu \mathrm{l}$ de $\mathrm{NaCl} 20 \%$ e $1 \mathrm{ml}$ de etanol, incubando-se a mistura a $-20^{\circ} \mathrm{C}$ por 18 horas. O sobrenadante foi desprezado, e o precipitado tratado com $20 \mu \mathrm{l}$ de dissociador da amostra (3\% SDS, 12,5\% Tris/HCl 0,5M pH 6,8, $5 \%$ 2-mercaptoetanol, $0,005 \%$ azul de bromofenol, $40 \%$ glicerol), e incubado por 30 minutos a $37^{\circ} \mathrm{C}$. A eletroforese foi realizada em gel de poliacrilamida 7,5\%, tampão Tris/glicina (Tris $0,025 \mathrm{M}$, glicina $0,109 \mathrm{M} \mathrm{pH} 8,3$ ), e uma corrente de $20 \mathrm{~mA} /$ placa, durante duas horas. O processo de coloração com nitrato de prata foi realizado de acordo com Herring et al. (1982).

No EIE para rotavírus e adenovírus, as microplacas, de fundo plano, com 96 cavidades foram sensibilizadas com soro hiperimune de

\footnotetext{
${ }^{7}$ Acros Organics - Geel, Bélgica.

${ }^{8}$ Bio-Rad Model 550 - Hercules, EUA.

${ }^{9}$ Kit EIARA, Fundação Oswaldo Cruz - Rio de Janeiro, Brasil.
} 
cabra anti-rotavírus e com soro hiperimune de cabra anti-adenovírus (1:10000) em TCB $0,025 \mathrm{M}, \mathrm{pH} 9,6$ overnight a $4^{\circ} \mathrm{C}$. As lavagens das microplacas e as diluições foram feitas com PBS-T contendo $1 \%$ de soroalbumina bovina. As incubações foram realizadas em banho-maria por 30 minutos à temperatura de $40^{\circ} \mathrm{C} \pm 2{ }^{\circ} \mathrm{C}$. Em seguida, foram adicionadas as suspensões fecais e os controles positivos para rotavírus e adenovírus, nas diluições de 1:4 e 1:12. As microplacas receberam, na fase subseqüente, os soros detectores (soro imune de cobaia antirotavírus e soro imune de cobaia anti-adenovírus, na diluição de 1:10000). Adicionou-se a diluição ideal do conjugado imunoenzimático (1:10000). Para completar a reação foram adicionados às microplacas solução cromógena de tetrametilbenzidina (TMB) a $0,1 \mathrm{mg} / \mathrm{ml}$ em tampão de ácido cítrico $0,1 \mathrm{M}$ e fosfato $0,2 \mathrm{M}, \mathrm{pH}$ 5,6 acrescida de peróxido de hidrogênio a $3 \%$. Após 15 minutos de incubação à temperatura ambiente, e ao abrigo da luz, a reação foi bloqueada pela adição de ácido sulfúrico 2,0M. As leituras das DO da reação foram realizadas em leitor de microplacas, a um comprimento de onda de $450 \mathrm{~nm}$. Foram consideradas positivas para rotavírus e adenovírus as amostras cujas DO foram o dobro da média das densidades ópticas obtidas no controle do conjugado.

O conjunto de dados referentes aos títulos de anticorpos anti-rotavírus foi submetido à análise de variância, e as médias geométricas foram comparadas entre si pelo teste Tukey. As diferenças foram consideradas significativas quando $\mathrm{P}<0,05$. A possibilidade de uma associação entre os títulos de anticorpos anti- rotavírus mensurados no soro sangüíneo dos bezerros e a detecção de rotavírus nas fezes desses foi avaliada pelo teste de qui-quadrado $\left(\chi^{2}\right)$ e, quando necessário, pelo teste exato de Fischer (User's..., 1999).

\section{RESULTADOS}

A distribuição dos diferentes isótipos de anticorpos anti-rotavírus no soro sangüíneo e no colostro das vacas imunizadas e não imunizadas é mostrada na Tab. 1. Tanto no soro sangüíneo como no colostro, os títulos dos isótipos IgG, IgG1 e IgG2 foram mais elevados no grupo dos animais vacinados, porém somente no colostro o aumento foi significativo. Por outro lado, no grupo de animais não vacinados, foi constatado aumento significativo nos títulos do isótipo $\operatorname{IgM}$ no soro sangüíneo.

Os títulos de anticorpos anti-rotavírus no soro sangüíneo dos bezerros alimentados com colostro das vacas vacinadas e não vacinadas são mostrados na Tab. 2. Os bezerros alimentados com colostro de vacas imunizadas apresentaram títulos de anticorpos baixos à zero hora de idade, para todos os isótipos. Às 24 horas de idade, foram verificados níveis máximos para os isótipos $\operatorname{IgG}, \operatorname{IgG} 2$, IgA e IgM. Após esse intervalo de tempo, os títulos destes isótipos começaram a declinar, exceto os do isótipo IgG1, que apresentou, às 48 horas de idade, níveis máximos no soro dos bezerros. Dos sete aos 28 dias de idade, os títulos dos isótipos $\operatorname{IgG}, \operatorname{IgG} 1$, IgG2 e IgA declinaram gradativamente, enquanto os níveis do isótipo IgM se elevaram aos 28 dias.

Tabela 1. Títulos de anticorpos anti-rotavírus (média \pm desvio-padrão) detectados no dia do parto no soro sangüíneo e no colostro de vacas imunizadas (grupo I) e não imunizadas (grupo II) com vacina contra rotavírus, por meio do EIE indireto

\begin{tabular}{|c|c|c|c|c|c|}
\hline \multirow{2}{*}{$\begin{array}{c}\text { Amostra e } \\
\text { grupo }\end{array}$} & \multicolumn{5}{|c|}{ Título de anticorpos anti-rotavírus } \\
\hline & IgG & IgG1 & $\operatorname{IgG} 2$ & $\operatorname{Ig} \mathrm{A}$ & $\operatorname{IgM}$ \\
\hline \multicolumn{6}{|c|}{ Soro sangüíneo } \\
\hline I & $1,762 \pm 0,727 \mathrm{a}$ & $0,195 \pm 0,067 \mathrm{a}$ & $0,128 \pm 0,033 a$ & $0,010 \pm 0,008 \mathrm{a}$ & $1,065 \pm 0,474 a$ \\
\hline II & $1,580 \pm 0,595 \mathrm{a}$ & $0,158 \pm 0,058 \mathrm{a}$ & $0,099 \pm 0,040 \mathrm{a}$ & $0,030 \pm 0,033 \mathrm{a}$ & $1,540 \pm 0,664 b$ \\
\hline \multicolumn{6}{|l|}{ Colostro } \\
\hline I & $21,218 \pm 4,197 \mathrm{a}$ & $2,248 \pm 0,268 \mathrm{a}$ & $0,077 \pm 0,026 \mathrm{a}$ & $0,601 \pm 0,209 a$ & $5,583 \pm 2,375 a$ \\
\hline II & $12,864 \pm 6,999 \mathrm{~b}$ & $1,665 \pm 0,575 b$ & $0,044 \pm 0,020 \mathrm{~b}$ & $0,683 \pm 0,164 a$ & $5,749 \pm 2,038 \mathrm{a}$ \\
\hline
\end{tabular}

Médias seguidas por letras distintas na coluna diferem entre si pelo teste Tukey $(\mathrm{P}<0,05)$. 
Tabela 2. Títulos de anticorpos anti-rotavírus (média \pm desvio-padrão) mensurados no soro sangüíneo dos bezerros alimentados com o colostro de vacas imunizadas (grupo I) e não imunizadas (grupo II) pelo EIE indireto, segundo a idade dos animais, e a detecção de amostras positivas para rotavírus pelo EIE, segundo a idade dos animais e a consistência das fezes

\begin{tabular}{|c|c|c|c|c|c|c|c|c|c|}
\hline \multirow{2}{*}{ Grupo } & \multirow{2}{*}{$\begin{array}{l}\text { Faixa } \\
\text { etária }\end{array}$} & \multicolumn{5}{|c|}{ Título de anticorpos anti-rotavírus no soro sangüíneo } & \multirow{2}{*}{$\begin{array}{c}\text { Amostra } \\
\text { diarréica } \\
\text { Amostra }+/ \\
\text { Total }\end{array}$} & \multirow{2}{*}{$\begin{array}{c}\begin{array}{c}\text { Amostra } \\
\text { normal }\end{array} \\
\begin{array}{c}\text { Amostra+l } \\
\text { Total }\end{array}\end{array}$} & \multirow{2}{*}{$\begin{array}{c}\text { Total } \\
\begin{array}{c}\text { Amostra }+ \\
\text { Total }\end{array}\end{array}$} \\
\hline & & $\operatorname{IgG}$ & IgG1 & $\operatorname{IgG} 2$ & $\operatorname{IgA}$ & $\operatorname{IgM}$ & & & \\
\hline I & \multirow[b]{2}{*}{$0 \mathrm{~h}$} & $\begin{array}{c}0,033 \pm \\
0,023 \mathrm{a}\end{array}$ & $\begin{array}{l}0,001 \pm \\
0,001 \mathrm{a}\end{array}$ & $\begin{array}{l}0,002 \pm \\
0,001 \mathrm{a}\end{array}$ & $\begin{array}{l}0,001 \pm \\
0,000 \mathrm{a}\end{array}$ & $\begin{array}{l}0,035 \pm \\
0,014 \mathrm{a}\end{array}$ & $0 / 0$ & $0 / 13$ & $0 / 13$ \\
\hline II & & $\begin{array}{l}0,025 \pm \\
0,018 \mathrm{a}\end{array}$ & $\begin{array}{l}0,003 \pm \\
0,002 \mathrm{a}\end{array}$ & $\begin{array}{l}0,001 \pm \\
0,001 \mathrm{a}\end{array}$ & $\begin{array}{l}0,001 \pm \\
0,001 \mathrm{a}\end{array}$ & $\begin{array}{l}0,017 \pm \\
0,013 a\end{array}$ & $0 / 0$ & $0 / 13$ & $0 / 13$ \\
\hline I & \multirow{2}{*}{$24 \mathrm{~h}$} & $\begin{array}{r}2,803 \pm \\
1,047 a\end{array}$ & $\begin{array}{l}0,267 \pm \\
0,079 \mathrm{a}\end{array}$ & $\begin{array}{l}0,031 \pm \\
0,013 \mathrm{a}\end{array}$ & $\begin{array}{l}0,047 \pm \\
0,020 \mathrm{a}\end{array}$ & $\begin{array}{l}0,910 \pm \\
0,570 \mathrm{a}\end{array}$ & $0 / 2$ & $0 / 11$ & $0 / 13$ \\
\hline II & & $\begin{array}{r}2,307 \pm \\
1,237 \mathrm{a}\end{array}$ & $\begin{array}{l}0,240 \pm \\
0,085 \mathrm{a}\end{array}$ & $\begin{array}{l}0,019 \pm \\
0,010 \mathrm{~b}\end{array}$ & $\begin{array}{l}0,038 \pm \\
0,016 \mathrm{a}\end{array}$ & $\begin{array}{l}0,674 \pm \\
0,354 \mathrm{a}\end{array}$ & $0 / 2$ & $0 / 11$ & $0 / 13$ \\
\hline I & \multirow{2}{*}{$48 \mathrm{~h}$} & $\begin{array}{r}2,801 \pm \\
1,034 a\end{array}$ & $\begin{array}{l}0,283 \pm \\
0,055 \mathrm{a}\end{array}$ & $\begin{array}{l}0,030 \pm \\
0,012 \mathrm{a}\end{array}$ & $\begin{array}{l}0,034 \pm \\
0,014 \mathrm{a}\end{array}$ & $\begin{array}{l}0,798 \pm \\
0,487 \mathrm{a}\end{array}$ & $0 / 0$ & $0 / 13$ & $0 / 13$ \\
\hline II & & $\begin{array}{c}2,310 \pm \\
1,293 \mathrm{a}\end{array}$ & $\begin{array}{l}0,240 \pm \\
0,077 \mathrm{a}\end{array}$ & $\begin{array}{l}0,017 \pm \\
0,011 \mathrm{~b}\end{array}$ & $\begin{array}{r}0,029 \pm \\
0,013 \mathrm{a}\end{array}$ & $\begin{array}{l}0,605 \pm \\
0,325 \mathrm{a}\end{array}$ & $0 / 3$ & $0 / 10$ & $0 / 13$ \\
\hline I & \multirow{2}{*}{$7 d$} & $\begin{array}{c}2,564 \pm \\
0,918 \mathrm{a}\end{array}$ & $\begin{array}{l}0,274 \pm \\
0,044 \mathrm{a}\end{array}$ & $\begin{array}{c}0,024 \pm \\
0,009 \mathrm{a}\end{array}$ & $\begin{array}{l}0,012 \pm \\
0,008 \mathrm{a}\end{array}$ & $\begin{array}{l}0,379 \pm \\
0,282 \mathrm{a}\end{array}$ & $0 / 2$ & $2 / 11$ & $2 / 13$ \\
\hline II & & $\begin{array}{l}2,100 \pm \\
1,257 \mathrm{a}\end{array}$ & $\begin{array}{l}0,220 \pm \\
0,073 \mathrm{a}\end{array}$ & $\begin{array}{l}0,017 \pm \\
0,011 b\end{array}$ & $\begin{array}{l}0,012 \pm \\
0,006 \mathrm{a}\end{array}$ & $\begin{array}{l}0,324 \pm \\
0,189 \mathrm{a}\end{array}$ & $2 / 5$ & $0 / 08$ & $2 / 13$ \\
\hline I & & $\begin{array}{c}2,149 \pm \\
0,904 a\end{array}$ & $\begin{array}{l}0,260 \pm \\
0,059 \mathrm{a}\end{array}$ & $\begin{array}{c}0,023 \pm \\
0,010 \mathrm{a}\end{array}$ & $\begin{array}{l}0,004 \pm \\
0,002 \mathrm{a}\end{array}$ & $\begin{array}{c}0,117 \pm \\
0,059 \mathrm{a}\end{array}$ & $2 / 4$ & $0 / 09$ & $2 / 13$ \\
\hline II & $14 d$ & $\begin{array}{l}1,819 \pm \\
1,162 \mathrm{a}\end{array}$ & $\begin{array}{l}0,211 \pm \\
0,075 \mathrm{a}\end{array}$ & $\begin{array}{l}0,016 \pm \\
0,010 \mathrm{~b}\end{array}$ & $\begin{array}{l}0,007 \pm \\
0,004 \mathrm{a}\end{array}$ & $\begin{array}{l}0,112 \pm \\
0,053 \mathrm{a}\end{array}$ & $0 / 3$ & $0 / 10$ & $0 / 13$ \\
\hline I & & $\begin{array}{l}1,981 \pm \\
1,072 \mathrm{a}\end{array}$ & $\begin{array}{r}0,235 \pm \\
0,069 \mathrm{a}\end{array}$ & $\begin{array}{c}0,020 \pm \\
0,009 \mathrm{a}\end{array}$ & $\begin{array}{l}0,002 \pm \\
0,001 \mathrm{a}\end{array}$ & $\begin{array}{l}0,132 \pm \\
0,135 \mathrm{a}\end{array}$ & $1 / 2$ & $1 / 11$ & $2 / 13$ \\
\hline II & $21 \mathrm{~d}$ & $\begin{array}{l}1,613 \pm \\
1,000 \mathrm{a}\end{array}$ & $\begin{array}{l}0,209 \pm \\
0,076 \mathrm{a}\end{array}$ & $\begin{array}{l}0,014 \pm \\
0,010 \mathrm{a}\end{array}$ & $\begin{array}{l}0,005 \pm \\
0,002 \mathrm{a}\end{array}$ & $\begin{array}{l}0,085 \pm \\
0,060 \mathrm{a}\end{array}$ & $0 / 0$ & $0 / 13$ & $0 / 13$ \\
\hline I & & $\begin{array}{l}1,676 \pm \\
0,798 \mathrm{a}\end{array}$ & $\begin{array}{r}0,218 \pm \\
0,068 \mathrm{a}\end{array}$ & $\begin{array}{l}0,018 \pm \\
0,007 \mathrm{a}\end{array}$ & $\begin{array}{r}0,003 \pm \\
0,001 \mathrm{a}\end{array}$ & $\begin{array}{c}0,210 \pm \\
0,165 \mathrm{a}\end{array}$ & $2 / 2$ & $1 / 11$ & $3 / 13$ \\
\hline II & $28 d$ & $\begin{array}{l}1,289 \pm \\
0,715 \mathrm{a}\end{array}$ & $\begin{array}{l}0,187 \pm \\
0,073 \mathrm{a}\end{array}$ & $\begin{array}{l}0,013 \pm \\
0,009 \mathrm{a}\end{array}$ & $\begin{array}{l}0,005 \pm \\
0,003 \mathrm{a}\end{array}$ & $\begin{array}{l}0,136 \pm \\
0,121 \mathrm{a}\end{array}$ & $0 / 4$ & $0 / 09$ & $0 / 13$ \\
\hline
\end{tabular}

$\overline{\text { Médias de uma mesma coluna, na mesma faixa etária, seguidas por letras distintas diferem entre si pelo teste Tukey }}$ $(\mathrm{P}<0,05)$.

Amostra $+=$ amostra positiva para rotavírus

Os bezerros alimentados com o colostro das vacas não imunizadas apresentaram um perfil cinético da resposta imune humoral semelhante ao do grupo I à zero hora de idade. Entre 24 e 48 horas, todos os isótipos alcançaram níveis máximos no soro dos bezerros. A partir desse intervalo, os títulos de $\operatorname{IgG}, \operatorname{IgG} 1, \operatorname{IgA}$ e $\operatorname{IgM}$ começaram a declinar. Comportamento idêntico foi observado com o isótipo IgG2 a partir dos 14 dias. Somente os títulos do isótipo $\operatorname{IgM}$ aumentaram aos 28 dias. Verificaram-se diferenças significativas apenas entre os títulos médios do isótipo IgG2 detectados às 24 e 48 horas e aos sete e 14 dias de idade.
Os resultados da detecção de rotavírus nas amostras de fezes dos bezerros alimentados com colostro das vacas vacinadas e não vacinadas são mostrados na Tab. 2. Das 11 amostras positivas pelo EIE, cinco também o foram pela técnica de EGPA, apresentando perfil de migração característico de rotavírus do grupo antigênico $\mathrm{A}$.

No grupo I, os primeiros casos positivos para rotavírus foram detectados aos sete dias de idade, sendo que dos 13 bezerros amostrados, dois $(15,4 \%)$ foram positivos, ambos sem manifestação clínica de diarréia. Aos 14 dias, somente foram encontrados casos positivos em dois $(15,4 \%)$ animais diarréicos. Aos 21 e 28 
dias, foram detectados casos positivos em amostras diarréicas e não diarréicas, com freqüências de $15,4 \%(2 / 13)$ e de $23,1 \%(3 / 13)$, respectivamente.

Dentre os 13 bezerros amostrados no grupo II, foi detectado rotavírus nas fezes de dois $(15,4 \%)$ animais com diarréia, cujas amostras foram obtidas aos sete dias de idade.

Apesar de os animais do grupo II, animais nascidos das vacas não imunizadas, terem apresentado maior número de episódios de diarréia, somente duas das 91 amostras de fezes $(2,2 \%)$ apresentaram resultado positivo para rotavírus. Nos animais do grupo I, animais nascidos das vacas imunizadas, foi detectado rotavírus em nove das 91 amostras $(9,9 \%)$, o que resultou em uma ocorrência significativamente maior que a observada no grupo II.

Pelo teste de $\chi^{2}$, não se observou associação significativa entre os níveis dos isótipos IgG, IgG1, IgG2, IGA e IgM no soro sangüíneo e a detecção de rotavírus nas fezes, nos bezerros do grupo I e II.

\section{DISCUSSÃO}

A diarréia neonatal é considerada um dos principais problemas sanitários que afetam os rebanhos bovinos, causando grandes prejuízos econômicos (Woode e Bridger, 1975). Considerando-se a importância clínica e a precocidade da infecção por rotavírus (Tzipori, 1981), a ingestão do colostro pelos neonatos, logo após o parto, é fundamental para a aquisição de anticorpos, já que nos ruminantes não ocorre uma efetiva transferência de imunoglobulinas durante a gestação (Robison et al., 1988). A fim de aumentar os níveis de anticorpos específicos contra rotavírus no colostro, recomenda-se a vacinação parenteral das vacas prenhes, uma vez que a maioria dos animais adultos possui anticorpos anti-rotavírus, adquiridos pela imunização ativa natural e que são facilmente estimulados pelos vírus vacinais (Bellinzoni et al., 1989; Conner et al., 1994).

Verificou-se que a imunização das vacas prenhes com a vacina comercial de rotavírus inativado aumentou significativamente os títulos de anticorpos anti-rotavírus dos isótipos $\mathrm{IgG}, \mathrm{IgG1}$ e IgG2 no colostro. Resultados semelhantes foram descritos por Saif et al. (1984) e Fernandez et al. (1996), que relataram aumento dos níveis de anticorpos anti-rotavírus no colostro dos animais imunizados com vacina de rotavírus inativado, relacionado principalmente aos isótipos IgG1 e IgA.

Os altos títulos do isótipo IgM verificados no soro sangüíneo e no colostro das vacas não vacinadas pode ser forte indicativo da ocorrência de infecções assintomáticas nos animais adultos, uma vez que este isótipo corresponde à principal classe de imunoglobulina relacionada com a resposta imune primária (Tizard, 2002).

A análise do soro sangüíneo dos bezerros nascidos das vacas imunizadas e não imunizadas revelou títulos médios de anticorpos antirotavírus muito baixos à zero hora de idade, porém, às 24 horas de idade, os bezerros dos dois grupos apresentaram títulos de anticorpos adquiridos via imunidade passiva, verificou-se neste momento níveis máximos para a maioria dos isótipos. Em ambos os grupos, verificou-se pequena elevação de $\operatorname{IgM}$ aos 28 dias de idade, sugerindo resposta imune ativa nos animais. A presença de rotavírus nos rebanhos estudados foi confirmada pela detecção do agente viral nas fezes dos bezerros dos dois grupos experimentais, com taxas de ocorrência de 9,9\% (9/91) no grupo de bezerros nascidos das vacas vacinadas e de $2,2 \%$ (2/91) no grupo de bezerros nascidos vacas não vacinadas.

Comportamento semelhante foi encontrado por Fernandez et al. (1998) que também observaram baixos títulos de anticorpos anti-rotavírus no soro sangüíneo e nas fezes dos bezerros duas horas após o nascimento e verificaram ainda que os títulos de anticorpos elevaram-se significativamente após a primeira mamada, sendo que os bezerros alimentados com o colostro das vacas imunizadas apresentaram predominância de IgG1 no soro sangüíneo. Nos bezerros nascidos das vacas não imunizadas, os títulos de IgM se elevaram, no soro e nas fezes, sete dias após o desafio com rotavírus, indicando a ocorrência de resposta imune ativa. Nos bezerros nascidos das vacas imunizadas, a resposta imune ativa foi mais tardia e menos intensa, indicando que os anticorpos maternos 
poderiam estar suprimindo a resposta imune ativa.

Com relação ao nível de proteção conferido aos bezerros, Snodgrass et al. (1980) verificaram que a vacinação materna apenas retardou o início da diarréia nos bezerros submetidos à exposição viral, sem reduzir a sua gravidade. Em condições de campo, McNulty e Logan (1987) observaram que a vacinação materna protegeu os bezerros da infecção viral. Kohara et al. (1997), ao trabalharem sob as mesmas condições, não verificaram diferenças na proteção dos bezerros, ressaltando ainda que a estirpe de rotavírus circulante era diferente da estirpe vacinal.

O menor número de amostras positivas para rotavírus detectado na propriedade rural onde não foi realizada a vacinação sugere que a circulação do agente viral entre os animais foi suficiente para estabelecer um estado de imunização natural mais eficiente quando comparado com o uso de vacina contra rotavírus.

Neste estudo, apesar de terem sido verificados títulos mais elevados da maioria dos isótipos analisados ao longo do tempo nos bezerros nascidos dos animais imunizados, a vacinação materna contra rotavírus não protegeu de forma efetiva os bezerros das infecções naturais por rotavírus, pois um número significativamente maior de bezerros nascidos das vacas imunizadas foi acometido pela rotavirose. Também não foi encontrada relação entre a imunidade passiva no soro sangüíneo e a detecção do agente viral nas fezes.

\section{AGRADECIMENTOS}

Os autores agradecem à FAPESP, pelo auxílio financeiro $\mathrm{e}$ ao Laboratório Biogenesis Argentina, pelo fornecimento do antígeno de rotavírus bovino.

\section{REFERÊNCIAS BIBLIOGRÁFICAS}

BELLINZONI, R.C.; BLACKHALL, J.; BARO, $\mathrm{N}$. et al. Efficacy of an inactivated oil-adjuvanted rotavirus vaccine in the control of calf diarrhoea in beef herds in Argentina. Vaccine, v.7, p.263$269,1989$.

CASTRUCCI, G.; FRIGERI, F.; FERRARI, M. et al. The protection of newborn calves against experimental rotavirus infection by feeding mammary secretions from vaccinated cows. Microbiologica, v.11, p.379-385, 1988.

CONNER, M.E.; MATSON, D.O.; ESTES, M.K. Rotavirus vaccines and vaccination potencial. In: RAMIG, R.F. (Ed). Rotaviruses. Berlin: Springer-Verlag, 1994. p.285-337.

FERNANDEZ, F.M.; CONNER, M.E.; PARWANI, A.V. et al. Isotype-specific antibody responses to rotavirus and virus proteins in cows inoculated with subunit vaccines composed of recombinant SA11 rotavirus core-like particles (CLP) or virus-like particles (VLP). Vaccine, v.14, p.1303-1312, 1996.

FERNANDEZ, F.M.; CONNER, M.E.; HODGINS, D.C. et al. Passive immunity to bovine rotavirus in newborn calves fed colostrum supplements from cows immunized with recombinant SA11 rotavirus core-like particle (CLP) or virus-like particle (VLP) vaccines. Vaccine, v.16, p.507-516, 1998.

HERRING, A.J., INGLIS, N.F., OJEH, C.K. et al. Rapid diagnosis of rotavirus infection by direct detection of viral nucleic acid in silverstained polyacrylamide gels. J. Clin. Microbiol., v.16, p.473-477, 1982.

KOHARA, J.; HIRAI, T.; MORI, K. et al. Enhancement of passive immunity with maternal vaccine against newborn calf diarrhea. J. Vet. Med. Sci., v.59, p.1023-1025, 1997.

LUCCHELLI, A.; LANCE, S.E.; BARTLETT, P.B. et al. Prevalence of bovine group A rotavirus shedding among dairy calves in Ohio. Am. J. Vet. Res., v.53, p.169-174, 1992.

McNULTY, M.S.; LOGAN, E F. Effect of vaccination of the dam on rotavirus infection in young calves. Vet. Rec., v.120, p.250-252, 1987.

MENANTEAU-HORTA, A.M.; AMES, T.R.; JOHNSON, D.W. et al. Effect of maternal antibody upon vaccination with infectious bovine rhinotracheitis and bovine virus diarrhea vaccines. Can. J. Comp. Med., v.49, p.10-14, 1985.

PARREÑO, V.; BÉJAR, C.; VAGNOSSI, A. et al. Modulation by colostrum-acquired maternal antibodies of systemic and mucosal antibody responses to rotavirus in calves experimentally challenged with bovine rotavirus. Vet. Immunol. Immunopathol., v.100, p.7-24, 2004. 
PEREIRA, H.G.; AZEREDO, R.S.; LEITE, J.P.J. et al. Eletrophoretic study of the genome of human rotaviruses from Rio de Janeiro, São Paulo e Pará, Brazil. J. Hyg., v.80, p.117-125, 1983.

PEREIRA, H.G.; AZEREDO, R.S.; LEITE, J.P.J. et al. A combined enzyme immunoassay for rotavirus and adenovirus (EIARA). J. Virol. Methods, v.10, p.21-28, 1985.

ROBISON, J.D.; STOTT, G.H.; DENISE, S.K. Effects of passive immunity on growth and survival in the dairy heifer. J. Dairy Sci., v.71, p.1283-1287, 1988.

SAIF, L.J.; REDMAN. D.R.; SMITH, K.L. et al. Passive immunity to bovine rotavirus in newborn calves fed colostrum supplements from immunized or nonimmunized cows. Infect. Immun., v.41, p.1118-1131, 1983.

SAIF, L.J.; SMITH, K.L.; LANDMEIER, B.J. et al. Immune response of pregnant cows to bovine rotavirus immunization. Am. J. Vet. Res., v.45, p.49-58, 1984.

SANT'ANA, V.A.C.; BIRGEL, E.H. Obtenção do soro lácteo para fracionamento das proteínas por eletroforese em gel de poliacrilamida. In: CONGRESSO LATINO AMERICANO DE
BUIATRIA, 11., 2003, Salvador. Anais... Salvador, 2003. CD-ROM.

SNODGRASS, D.R.; FAHEY, K.J.; WELLS, P.W. et al. Passive immunity in calf rotavirus infections: maternal vaccination increases and prolongs immunoglobulin G1 antibody secretion in milk. Infec. Immun., v.28, p.344-349, 1980.

SNODGRASS, D. R.; TERZOLO, H.R; SHERWOOD, D. et al. Aetiology of diarrhoea in young calves. Vet. Rec., v.119, p.31-34, 1986.

TIZARD, I.R.(Ed). Imunologia veterinária: uma introdução. 6.ed. São Paulo: Roca, 2002. p.233246.

TSUNEMITSU, H.; SHIMIZO, M.; HIRAI, T. et al. Protection against bovine rotaviruses in newborn calves by continuous feeding of immune colostrums. J. Vet. Sci., v.51, p.300-308, 1989.

TZIPORI, S. The aetiology and diagnosis of calf diarrhoea. Vet. Rec., v.108, p.510-513, 1981.

USER'S guide. Release 6, 12 TS level 0020. Cary, NC: SAS Institute, 1999. p.519-548.

WOODE, G.N.; BRIDGER, J.C. Viral enterits of calves. Vet. Rec., v.96, p.85-88, 1975. 